Institute of $\mathbf{F}_{\text {ood and }} \mathbf{A}_{\text {gricultural }} \mathbf{S}_{\text {ciences }}$

\title{
2003 Handbook of Employment Regulations Affecting Florida Farm Employers and Workers: Florida Landlord-Tenant Law [State] ${ }^{1}$
}

\author{
Leo C. Polopolus, Michael T. Olexa, Fritz Roka, and Carol Fountain ${ }^{2}$
}

\section{Purpose}

Defines terms for termination of tenancy by either party.

\section{Program}

The Florida Landlord-Tenant Law was amended in 1981 to include housing provided to employees as an incidence of employment with or without the payment of rent. If the dwelling unit is furnished without rent as an incident of employment and there is no agreement as to the duration of tenancy, the duration is determined by the periods for which wages are payable (i.e., weekly, monthly, etc.).

\section{Notice Requirements}

A tenancy without a specific duration may be terminated by either party giving written notice as follows:

\begin{tabular}{ll}
\hline Tenancy & \multicolumn{1}{c}{ Notice } \\
\hline Yearly & $\begin{array}{l}\text { At least sixty days prior to the } \\
\text { end of the annual period. }\end{array}$ \\
Quarterly & $\begin{array}{l}\text { At least thirty days prior to the } \\
\text { end of the quarterly period. }\end{array}$ \\
Monthly & $\begin{array}{l}\text { At least fifteen days prior to the } \\
\text { end of the monthly period. }\end{array}$ \\
Weekly & $\begin{array}{l}\text { At least seven days prior to the } \\
\text { end of the weekly period. }\end{array}$ \\
\hline
\end{tabular}

1. This is EDIS document FE400, a publication of the Department of Food and Resource Economics, Florida Cooperative Extension Service, Institute of Food and Agricultural Sciences, University of Florida, Gainesville, FL. Published July 2003. This information is included in Circular 1200, Handbook of Employment Regulations Affecting Florida Farm Employers and Workers. First published February 1992 as Circular 1043 . Revised December 2002 as Circular 1200. Please visit the EDIS website at http://edis.ifas.ufl.edu.

2. Leo C. Polopolus, Professor Emeritus, Department of Food and Resource Economics, University of Florida, Gainesville, FL; Michael T. Olexa, Professor, Department of Food and Resource Economics, University of Florida, Gainesville, FL; Fritz Roka, Associate Professor, Department of Food and Resource Economics, Southwest Florida Research and Education Center, Immokalee, FL; and Carol Fountain, Assistant Editor, Department of Food and Resource Economics, University of Florida, Gainesville, FL; Florida Cooperative Extension Service, Institute of Food and Agricultural Sciences, University of Florida, Gainesville, FL.

This document is designed to provide accurate, current, and authoritative information on the subject. However, since the laws, administrative rulings, and court decisions on which it is based are subject to constant revision, portions of this publication could become outdated at any time. This publication is distributed with the understanding that the authors are not engaged in rendering legal or other professional advice, and the information contained herein should not be regarded as a substitute for professional advice. For these reasons, the utilization of these materials by any person constitutes an agreement to hold harmless the authors, the Institute of Food and Agricultural Sciences, and the University of Florida for any liability claims, damages, or expenses that may be incurred by any person as a result of reference to or reliance on the information contained in this publication.

The Institute of Food and Agricultural Sciences is an equal opportunity/affirmative action employer authorized to provide research, educational information and other services only to individuals and institutions that function without regard to race, color, sex, age, handicap, or national origin. For information on obtaining other extension publications, contact your county Cooperative Extension Service office. Florida Cooperative Extension Service/Institute of Food and Agricultural Sciences/University of Florida/Christine Taylor Waddill, Dean. 


\section{Additional Information}

- Chapter 83, Florida Statutes. 